\title{
Sustainable Financial System with View of System Effectiveness and Efficiency in China
}

\author{
Wei Zhong \\ Yunnan University of Finance \& Economics \\ Yunnan, 650221 China \\ wzh@ynufe.edu.cn
}

\begin{abstract}
China has experienced high growth rate of GDP for nearly 30 years and accumulated production surplus, which contributed to the development of financial system of China. View of sustainable development is widely accepted to regulate the development of economy and environmental protection. This article analyzes the issues of current China's financial development, and positively construct a research framework of the sustainable financial system in China from the perspective of view of sustainable development. A deterministic philosophy and deductive method was applied to address the subjects. The paper explicitly inferenced the connotation of the sustainable development of financial system and made a detailed explanation being founding three constructs as system effectiveness, efficiency and fairness, and a research framework was put forward.
\end{abstract}

Keywords-sustainable financial system; financial system efficiency; financial system effectiveness; fairness

\section{INTRODUCTION}

Financial system and development is an important topic for transition economies. In recent years, financial system development has gained increasing attention, both in academic and policy circles. When China started the process of economic and political transition from the late 1980s, one of the key policy issues was how she should design her domestic financial system.

The concept of "financial sustainable development" can be seen in Chinese scholars' research literature. We have found that the concept of sustainable development in the literature $(\mathrm{Hu})$ is still a concept of development and there is no sustainable development in finance. View of sustainable development is defined. The literature (Bai) discussed theoretically the concept of financial sustainable development and put forward the theory of financial sustainable development based on the theory of financial resources, and considers the theory of financial sustainable development. In this way, financial development will not only affect whether a country's macroeconomic policies can be transferred in a timely and effective manner, but also whether macroeconomic policies can successfully achieve the desired goals; the rapid economic development will increase the national income and stimulate the increase in the number of economic entities. The demand for financial services can further promote the further development of finance and form a virtuous circle of "financial development"-“economic development"-“further development of finance" — "one-step economic development" and achieve sustainable financial development. Studying the optimal allocation and efficiency optimization of financial resources should take into account of fairness, and advocating the rational use of financial resources and benign distribution among generations.

Attention has recently been directed to the study of the financial system as a whole. The positive contribution the financial system can make to the process of economic growth depends on how the system is designed. Knowledge of exactly how the design of the financial system may help to improve welfare is of course of particular significance to transition economies, since they still have options to influence the direction of development of their financial systems. Sustainable financial system is becoming a warm topic among academia.

Thus, this paper is about to construct a sustainable view of financial system development, being a modest one of providing some positive evidence on issues of Chinese financial system and introduce a research framework to follow in the near future. A deterministic philosophy and deductive method were applied to address the issues.

The literature review will cover the view of sustainable development, the major facts and issues of current Chinese financial system development from subtopics(financial system efficiency and effectiveness, fairness), followed section III by detailed study on the system inefficiency and construct deficiency issues which arise for questing for measures to be done to reduce or eliminate the risks within. Thereafter, section IV leads to the solution as the connotation of sustainable financial development, and detailed explanation of the connotation with pertinence to the potential risks of Chinese financial systems. End with section $\mathrm{V}$ with conclusions.

\section{LITERATURE REVIEW}

To deliver the required transformation in the financial system, a performance framework is needed so progress can be measured. This framework would allow governments, IFs, and citizens to identify successful approaches, as well as areas lagging behind, thereby laying the basis for strategic adjustments in both policy and practice (Zheng and Luo). Over the past several years, increasing efforts have been placed on how to measure the contribution of the financial system to sustainable development, specifically in the environmental 
dimension. Measuring progress to a sustainable financial system involves gaining an understanding of two core performance characteristics:

Effectiveness: The degree to which the market prices sustainability factors in asset valuations.

Efficiency: The costs of running the financial system that delivers the flows of finance aligned with sustainable development requirements.

\section{A. Chinese Financial Development and Risks}

A number of scholar study date back before the American subprime crisis and earlier than 1997-Asian-financial-crisis. Gertler, et al. and A.V. Thakor survey theoretical literature on financial development and economic growth, while De \& Leng provide an overview of empirical evidence with a specific focus on stock market development. R. Levine provides a comprehensive, up-to-date review of theoretical and empirical studies. In F. Allen and D. Gale, the market-dominated US financial system and the bank-dominated German financial system are compared in their capacity to provide risk-sharing opportunities. It is argued that bank-dominated systems are better at providing intertemporal risk sharing through longterm commitments while market-dominated systems provide better cross-sectional risk sharing by providing a more diverse set of financial instruments. Informational asymmetry is central to Boot and A.V.Thakor who analyze the borrower's choice between bank and financial market funding.

Many Chinese scholars research the financial development and economic growth. Among them, the research on financial development systemically is plentiful (Xie;Yi;Zhao). Simultaneously, the Chinese empirical study on the theory of financial development and economic growth can be seen after the middle 1990s. Hu researched the contribution of China capital investment on economic growth from the macro level. Fan studied some issue of China financial development, enterprise reform and development. Wang and Sun took Granger causality check method to examine the relationship of financial development and economic growth from three aspects: scale expansion, structure adjustment and efficiency.

\section{B. Chinese Financial System Efficiency}

Contrary to the conventional wisdom that government intervention in the financial system limits economic growth, Chinese scholars generally agree that strong control of the financial system by the Chinese government was conducive to economic growth (Xie). They recognize at the same time that further economic growth is hindered by financial regression, calling for comprehensive measures of financial liberalization. Here we take a brief look at the evolutionary path of the Chinese financial system.

Zhou did an empirical study on the regional finance development and economic growth in China in the period from 1978 to 2000, and found that there was a close relationship between finance and economic growth in every region of China. Financial development accelerates economic growth and financial development gap can partially explain economic gap. Initial financial development level can partially explain economic performance in the future. Financial marketization has very close relation to economic growth. Financial opening can promote financial development. China should try to find the right way to open financial market. But this research is still from financial market way. Cao and $\mathrm{Wu}$ supplemented the causality check of the relationship between financial intermediation and economic growth by the Granger causality check way, and considered the financial intermediation development plays a crucial role in economic growth. The acceleration was boosted by the quantity expansion of financial assets. Nevertheless, $\mathrm{Li}$ and Chen concluded that financial intermediation development and economic growth have no causality in any direction, and there was bidirectional causality between the financial intermediation efficiency and economic growth. Han are the first research in China to use the concept and method of "capital allocation efficiency" to study the relationship between the financial development and economic growth. They did quantitative analysis on the data of 39 Chinese industrial sector and concluded the low capital allocation efficiency in China. However, the data of this research didn't include beyond the industrial.

\section{Chinese Financial System Effectiveness}

When studies begin from 1980s, the government tightly controlled banks in China and the functions of banks were not defined at all. For instance, while the People's Bank of China (the "PBOC") performed some of the responsibilities of a central bank, such as issuing currencies and formulating financial policies, it also conducted the business of a commercial bank.

Since the emergence of the Shanghai Stock Exchange and Shenzhen Stock Exchange in 1990, we have experienced massive institutional change of Chinese financial market. The events were a success of the functionalists, which broke up the monotone structure of indirect financing by state-owned banks (if putting aside the fiscal investment in state-owned enterprises). And it helped to embed a subsystem of direct financing into to whole financial system in China. For many reasons, from the outset, just state-owned enterprises (with some exceptions of collective-owned enterprises) are granted privileges of being listed. There is a hierarchy between the various types of shares differentiated by the owners: state shares, corporate shares and public shares. From 1993, the State Council adopted a Decision on Financial Structure Reforms, which requires the adopting of relevant laws and regulations, the reform of the central bank, the establishment of policy banks and the reform of the foreign exchange system.

Despite various liberalization measures of the financial system, the process of liberalization was rather slow especially in such areas as deregulation of interest rates, reduction of policy loans and enhancement of autonomy in bank management. On the other hand, we witnessed the rapid growth of nonblank financial intermediaries, which were not the target of strict government regulation. After China enters into the WTO, the financial system is gradually open more and more, and the bank inefficiency is gradually changed. 


\section{View of Sustainable Development}

Sustainable development is the organizing principle for meeting human development goals while at the same time sustaining the ability of natural systems to provide the natural resources and ecosystem services upon which the economy and society depend. The desired result is a state of society where living conditions and resource use continue to meet human needs without undermining the integrity and stability of the natural system. Sustainable development can be classified as development that meet the needs of the present without compromising the ability of future generations.

Financial system is key force to redistribute the production resources for higher profitability. The system aggregates the capital, which is one of the two key inputs to production system. Thus, government need to consider the balance view of the role of financial system as an approach to achieve the sustainable development goal.

\section{INEFFECTIVENESS AND INEFFICIENCY OF CHINESE FINANCIAL SYSTEM}

The foundation of finance is currency surplus and credit. The role of finance in promoting the economy is reflected by the two relatively independent categories of currency and credit money facilitates exchange and trade with its own attributes, and provides new wealth accumulation. Form - Accumulation of money, thus creating the premise for the expansion of reproduction; Credit allows the most timely and full use of factors of production, and enables producers to expand their reproduction beyond their own capital accumulation, while also promoting the accumulation and concentration of capital; If any of these two gaps occur, there will be a crisis in financial support.

The concept of sustainable development is a concept that emerges when the economy develops to a certain state. It is a reflection of the traditional concept of development. It emphasizes the efficiency of resource allocation and the concept of fairness. It emphasizes the rational use and distribution of resources, and emphasizes the entire economic macro level. The fairness and efficiency of the intergenerational generation also emphasize the fairness and efficiency of the horizontal aspects of various systems. To understand the concept of financial sustainable development one needs to start from the actual situation of financial development, and then analyze why it is necessary to take financial sustainable development.

Due to the special background of China's financial development and the uniqueness of China's national conditions, financial development has also seen many problems. From the foundation of financial integrity to the allocation and use of financial resources, to the macroscopic structure and microstructure of finance, you can see inefficiency and uneven development.

\section{A. Credit Silo}

Chinese enterprises are also generally lacking in credibility, chaotic market order, and the lack of security sense of the people. Coupled with the backwardness of the national education system, people are earnestly looking forward to integrity, and the general crisis of confidence comes. Regarding the credibility crisis, Zhang and Li (2012) believed that its root cause is the unclear property rights system. The short-term behavior of enterprises is rooted in the defects of our current property rights system and government regulations. Through various argumentation findings, we believe that there is no perseverance among the permanent property owners. The non-persistent people have no credit, destroyed the property rights basis of credit, restricted free competition, and inevitably led to confusion in the market order and prevalence of fraud.

This is the reputation of the enterprise while the property rights system is not clear, and the capital market in China has become in policy cities, the price discovery function of the capital market did not play its due role. Zhang believed that China is currently in an excessive period from the picking economy to the market economy, and it is necessary to adapt the social credit system adapted to the market economy. To maintain, the key lies in the formation of the internal "contractual authority" concept and the establishment of an external "rule of law"; Xie analyzes China's credit performance, and finds that credits show inconsistent characteristics of distribution in various regions, and proof of regression analysis The level of non-performing loans is not related to economic growth due to the behavior of regional governments. Same, different credit risk coefficient of each region, but also different credit authorization, credit abused, resulting in a credit transfer phenomenon.

\section{B. Construct Deficiency}

From the perspective of the composition of financial assets, monetary financial assets are still the main body of China's financial assets. However, due to the rapid increase in securities financial assets, the proportion of its structure shows a downward trend. The proportion of corporate bonds and financial bonds is increasing, but not much, especially in recent years. The proportion of insurance financial assets has increased rapidly in recent years, but the proportion is still very low. The structure of social and financial assets has undergone significant changes with the changes in the structure of financial markets.

From the perspective of currency structure according to Chinese Financial Statistics data from year 2005 to 2016, the overall trend is that $\mathrm{M} 2$ is growing faster than M1, M1 is growing faster than M0, which reflects China's economic monetization process, and the proportion of M0 in the broad money M2 is declining year by year. The proportion of M1 in the broad money M2 also decreased year by year, reflecting that the economic monetization has developed to a certain extent. The imbalance is mainly manifested in the fact that indirect finance is too large and direct finance is too small. The proportion of loans financed by loans accounted for $90 \%$ in 2000. That is, in all financing, $90 \%$ is indirect financing and $10 \%$ is direct financing. The proportion of monetary financial assets is basically $72 \%$ in the whole society, and the proportion of marketable securities and financial assets has risen to $28 \%$. From the perspective of the structure of financial institutions, the main manifestations of imbalances are: banking financial institutions and non-banking finances. The development of 
institutions is uneven. State-owned commercial banks still play a decisive role. Other commercial banks, securities industry, insurance industry and urban and rural credit cooperatives have not fully played their roles and functions.

The above analysis shows that, in the financial supply and demand market, development still faces great challenges in terms of fairness and efficiency. Without fair and efficient development, it deviates from the concept of sustainable development, and its development will inevitably hurt itself. Disadvantages also appear in economic life.

\section{Market Imbalance}

Institutionally, the changes in the financial system depend on and lag behind changes in the economic system. Finance is to serve the economy. From the actual process of reform, the change of financial system has always depended on the changes of the economic system. There is an imitation of the changes in the economic system in terms of innovative choices in the arrangement of the financial system. Although China has initially established a financial market system, the market structure is somewhat out of balance. First, the financial derivatives trading market has not been established, and the current framework and operating rules of the gold market and foreign exchange market are far from meeting the needs of joining the WTO. The investment fund market is too single and narrow.

From the perspective of the development status of the money market, the capacity is small, the structure is imperfect, operations are not standardized, and development is lagging behind; at the same time, there is a lack of mechanisms for convergence and communication with the capital market. This not only restricts the further development of the capital market, but also exacerbates the speculative and volatile nature of the stock market. Second, the function of the financial market is distorted and the depth of market development is not enough. Under the planned economy system, the capital supply system is the basic feature of financial resources preparation. The development of markets, capital markets, and insurance markets lacks depth. Third, the lack of market objects, the main body is still not perfect.

Government financing is super-economically mandatory, financial regulation is weak, state-owned commercial banks fail to be truly commercialized, state-owned enterprises are softly constrained by budgets, residents have poor risk awareness, market credit bases are weak, financial innovation is insufficient, market liquidity is insufficient, and investment channels are insufficient, And social assets are concentrated in bank deposits, which seriously inhibits the efficiency of mobilization and allocation of financial resources.

Therefore, only through the establishment of a sustainable development model of financial development can we make financial development play a greater impetus for economic prosperity and development.

\section{THE CONNOTATION OF SUSTAINABLE FINANCIAL SYSTEM}

The financial industry is listed as "financial insurance" in the national economic system and belongs to the tertiary industry. The most direct performance of finance is to collect savings and then allocate savings resources, and partially play the role of resource distributors. China's original financial development was an extensive development model based on quantity, and it was a financial credit distribution model that was established in accordance with the planned economic system. Therefore, the utilization and configuration of financial resources did not reach the optimal state and effect. Under the market economy system, the reform of the financial system is shifting towards an intensive allocation of financial resources. We know that the content of economic research is the issue of full utilization and optimal allocation of resources. Its appeal is the maximization of social welfare and economic benefits. The study of sustainable development is also the allocation of resources, but its appeal is the use of resources.

Therefore, our core description of sustainable financial development is: to serve the sustainable development of the economy as the premise, emphasize the rational development and deployment of financial resources, take into account efficiency and fairness, and make the system structurally relevant in the process of financial development. It can meet the needs of previous and subsequent generations of economic and social development in terms of quantity; it can be embodied in a non-abuse of financial resources, reasonable in financial structure, and optimally configured in terms of quantity.

\section{CONCLUSIONS}

This paper reviewed the issues in Chinese financial development. From the systematic view the financial system as an important part of economy contribute to the directing of allocation of resources in various elementary markets. The dysfunctional issues explicitly presented as system inefficiency and unbalanced ineffectiveness with construct deficiency in service the support the development of economy. In China the financial resources are aggregated intensively as the outcome of traditional Chinese culture of life to the highest level. The financial system is experiencing the most difficult period to keep stable.

Sustainable development is the need for a combination of human wealth maximization and social welfare maximization. Financial sustainable development also has its own development goals. The paper found a construct of sound sustainable financial system. First, as an important part of the economic system, it must serve the economy. On the premise of sustainable development, financial development promotes economic development, and financial contribution to economic growth as an important part of the target system. Second, the financial system performs as an important social and economic functional service system.

Besides it requires the allocation of social and financial resources. It is necessary to rationalize and allocate its own aggregated resources. Therefore, efficiency is a core content of the financial sustainable development target system. Third, 
both fairness and financial sustainability must also reflect the connotation of fairness. The requirement for fairness in the development of financial objects requires the fairness of financial entities in development. It requires that financial development reflect fairness in the allocation of intergenerational resources, ensure the rational use of financial resources and optimize the allocation of resources, and minimize waste of resources. Repeatedly spread and make financial risk controllable it needs to gain maximum convenience and satisfaction when access to financial services, greatly improving social welfare and improving people's living standards, and improve the quality of life of the people as well.

The financial system is already transitioning to create, value, and transact financial assets in ways that shape real wealth to serve the long-term needs of an inclusive and more sustainable economy. Shifting to a sustainable financial system does not imply a change of the traditional functions of the financial sector. Rather, these functions can be realigned toward sustainable goals to ensure the growth of a more inclusive and sound financial sector, one that intermediates resources, enables payments, and facilitates risk management with increased efficiency and effectiveness.

Until a few years ago, sustainable finance in its many forms - climate and green finance being probably its most discussed area-was an area of interest mainly to a subset of practitioners in the financial sector. Today, sustainability is regarded as a fundamental component of the financial sector, essential to its soundness and effectiveness in fulfilling its intermediation role and contributing to a more inclusive world by providing broader access to financial services. There is a long way to pursue.

\section{REFERENCES}

[1] A.V. Thakor, "The design of financial systems: an overview," Journal of Banking and Finance, vol.20, pp. 917-948, July, 1996.

[2] Bai Qinxian, Introduce to Chinese Financial Development, Peking: Tsing-hua University, 2001, pp. 135-148.

[3] Cao Xiao and Wu Jun, "The Granger check on Chinese financial development and economic growth," Finance and Trade Economics, vol.5, pp.40-43, May, 2002
[4] De Kang and Leng Ruo, "Chinese stock market development status and financial intermediaries," The Journal of Economic Review, vol.113, pp. 91-100, February, 2016

[5] Fan Gang, Financial development and enterprise reform. Peking: Economic Science, 2000, pp. 26-77.

[6] F. Allen, D. Gale, "Financial markets, intermediaries, and intertemporal smoothing," Journal of Political Economy, vol.105, pp.523-546, March, 1995 .

[7] Gartler, Mark and Andrew Rose, Finance, Public Policy and Growth. Cambridge: Cambridge University, 1994, pp.14-38.

[8] Han Liyan, "Chinese capital allocated efficiency research based on panel data," Economics Quarterly, vol.1, pp.11-17, March, 2002.

[9] Hu Angang, "The characteristic of Chinese deflation and its causality," Management World, vol.3, pp.10-23, March, 1999.

[10] Hu Hongzhang, Chinese Financial System and Development, Peking: China Finance, 1997, pp. 89-103.

[11] Li Guangzhong and Chen Ping, "Financial intermediary's developmen and economic growth," Management World, vol.3, pp.35-44, March, 2002.

[12] R. Levine, "Financial development and economic growth: Views and agenda," Journal of Economic Literature, vol.35, pp. 699-726, February, 1997.

[13] Wang Zhi and Sun Gang. "The analysis of Chinese financia development on three aspects: scale, structure and efficiency,' Management World, vol.7, pp. 13-20, July, 2003

[14] Xie Ping, "Chinese financial assets structure analyze," Economic Research, vol.11, pp. 1-7, November, 1992.

[15] Xie Ping, Chinese Financial Corruption: Cause and Effect revisited, Peking: Chinese Economy, 2012.

[16] Yi Gang, "Analyze on the Chinese financial capital: a policy view," Economic Research, vol.11, pp.12-19, November, 1996.

[17] Zhang Weiying and Li Shuhe, "Regional competition and state-owned Enterprises reform,” Economics Study, vol.6, pp.12-22, June, 2012.

[18] Zhang YiChun, Study on the relationship between financial development and income of peasants in rural areas, Shanghai: Southern-eastern University, 2012.

[19] Zhao Zhijun, "Gross financial assets: structure and economic growth," Management World, vol.3, pp. 126-136, 2000

[20] Zheng Ming and LuoYong, "Managerial Ties and Firm Performance in A Transition Economy: The Nature of A Micro-macro Link," Academy of Chinese Management Journal, vol.143, pp. 486-501, 2015.

[21] Zhou Li, "Financial development and economic growth study on Chinese regions' data," Financial Research, vol.81, pp. 1-13, 2002. 